\title{
Record high levels of atmospheric ammonia over India: Spatial and temporal analyses
}

\author{
J. Kuttippurath ${ }^{\text {a,* }}$, A. Singh ${ }^{\text {a,b }}$, S.P. Dash ${ }^{\text {c }}$, N. Mallick ${ }^{\text {b }}$, C. Clerbaux ${ }^{\text {d,e }}$, M. Van Damme ${ }^{\text {e }}$, L. Clarisse ${ }^{\text {e }}$, \\ P.-F. Coheur ${ }^{\text {e }}$, S. Raj ${ }^{\text {a }}$, K. Abbhishek ${ }^{\text {a }}$, H. Varikoden ${ }^{\text {f }}$
}

a CORAL, Indian Institute of Technology Kharagpur, Kharagpur 721302, India

b Agricultural and Food Engineering Department, Indian Institute of Technology Kharagpur, Kharagpur 721302, India

c Department of Physics, Indian Institute of Technology Kharagpur, Kharagpur 721302, India

d LATMOS/IPSL, Sorbonne Université, UVSQ CNRS, Paris, France

e Université libre de Bruxelles (ULB), Service de Chimie Quantique et Photophysique, Atmospheric Spectroscopy, Brussels, Belgium

${ }^{\mathrm{f}}$ ESSO-Indian Institute of Tropical Meteorology Pune, India

\section{H I G H L I G H T S}

- A detailed analysis of atmospheric $\mathrm{NH}_{3}$ over India using satellite observations

- Intense agriculture and numerous fertilizer plants make the Indo-Gangetic Plain (IGP) as one of the largest $\mathrm{NH}_{3}$ hotspots of the world.

- There is a decreasing trend in annual atmospheric $\mathrm{NH}_{3}$ over India in accordance with the national missions and action plans.

- The IGP still shows an increasing trend in $\mathrm{NH}_{3}$ during the monsoon/Kharif season.

\section{G R A P H I C A L A B S T R A C T}

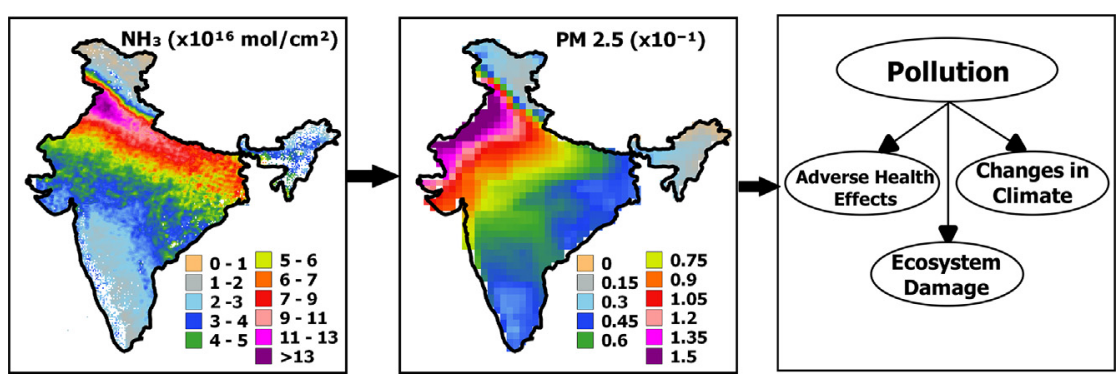

\section{A R T I C L E I N F O}

\section{Article history:}

Received 25 December 2019

Received in revised form 3 June 2020

Accepted 3 June 2020

Available online 5 June 2020

Editor: Jianmin Chen

\section{Keywords:}

Ammonia

Particulate matter

Climate change

Agriculture

Aerosols

IASI

India

\begin{abstract}
A B S T R A C T
Atmospheric ammonia $\left(\mathrm{NH}_{3}\right)$ is an alkaline gas and a prominent constituent of the nitrogen cycle that adversely affects ecosystems at higher concentrations. It is a pollutant, which influences all three spheres such as haze formation in the atmosphere, soil acidification in the lithosphere, and eutrophication in water bodies. Atmospheric $\mathrm{NH}_{3}$ reacts with sulfur $\left(\mathrm{SO}_{\mathrm{x}}\right)$ and nitrogen $\left(\mathrm{NO}_{\mathrm{x}}\right)$ oxides to form aerosols, which eventually affect human health and climate. Here, we present the seasonal and inter-annual variability of atmospheric $\mathrm{NH}_{3}$ over India in 2008-2016 using the IASI (Infrared Atmospheric Sounding Interferometer) satellite observations. We find that Indo-Gangetic Plains (IGP) is one of the largest and rapidly growing $\mathrm{NH}_{3}$ hotspots of the world, with a growth rate of $+1.2 \% \mathrm{yr}^{-1}$ in summer (June-August: Kharif season), due to intense agricultural activities and presence of many fertilizer industries there. However, our analyses show insignificant decreasing trends in annual $\mathrm{NH}_{3}$ of about $-0.8 \% \mathrm{yr}^{-1}$ in all India, about $-0.4 \% \mathrm{yr}^{-1}$ in IGP, and $-1.0 \% \mathrm{yr}^{-1}$ in the rest of India. Ammonia is positively correlated with total fertilizer consumption $(r=0.75)$ and temperature $(r=0.5)$ since high temperature favors volatilization, and is anti-correlated with total precipitation ( $\mathrm{r}=$ from -0.2 , but -0.8 in the Rabi season: October-February) as wet deposition helps removal of atmospheric $\mathrm{NH}_{3}$. This study, henceforth, suggests the need for better fertilization practices and viable strategies to curb emissions, to alleviate the adverse health effects and negative impacts on the ecosystem in the region. On the other hand, the overall decreasing trend in atmospheric $\mathrm{NH}_{3}$ over India shows the positive actions, and commitment to the national missions and action plans to reduce atmospheric pollution and changes in climate.
\end{abstract}

(C) 2020 Elsevier B.V. All rights reserved.

\footnotetext{
* Corresponding author.

E-mail address: jayan@coral.iitkgp.ac.in (J. Kuttippurath).
} 


\section{Introduction}

Atmospheric ammonia $\left(\mathrm{NH}_{3}\right)$ is very dynamic as it is constantly exchanged between atmosphere and biosphere. The major source of atmospheric $\mathrm{NH}_{3}$ is agriculture activities, such as the animal husbandry, nitrogenous fertilizers, manure management, and different soil and water management practices (Sutton et al., 1993; Adams et al., 2001; Murano et al., 1998). Atmospheric concentrations of $\mathrm{NH}_{3}$ are higher near agriculture sources, but later fade away due to conversion to aerosols and deposition on soils and water bodies (e.g. Zhang et al., 2010). It undergoes both dry deposition in the form of $\mathrm{NH}_{3}$ near its emission sources and wet deposition far away from its source as ammonium salts $\left(\mathrm{NH}_{4}^{+}\right)$. Dry deposition of $\mathrm{NH}_{3}$ has a relatively larger ecological impact than wet deposition by precipitation (Sheppard et al., 2011). The deposited $\mathrm{NH}_{3}$ in soils undergoes microbial nitrification that may limit the availability of micronutrients such as potassium $\left(\mathrm{K}^{+}\right)$and magnesium $\left(\mathrm{Mg}^{2+}\right)$ to plants in response to decrease in soil $\mathrm{pH}$ during the process.

Biomass burning produces unprecedented levels of nitrogen species (e.g. Hegg et al., 1988) and is the second-largest contributor to atmospheric $\mathrm{NH}_{3}$ after agriculture (e.g. Bouwman et al., 1997), about $13-16 \%$, although there is some uncertainty in these estimates (Whitburn et al., 2017). There is a strong seasonality in biomass burning, and both upper and lower bounds of these emissions are significant in terms of contributing to $\mathrm{NH}_{3}$ emissions (Behera et al., 2013). Most biomass burning and forest fire events are seasonal and episodic, which add more uncertainty to the emission estimates. In addition, as most burning events happen in the tropics, the source of emissions has a profound regional weightage (Whitburn et al., 2016a, 2016b). For instance, south Asia (including India) is one of the largest biomass burning affected regions in the world, and large columns of $\mathrm{NH}_{3}$ are detected from space in these areas (Whitburn et al., 2017; Sharma et al., 2020).

The Indo-Gangetic Plains (IGP) in India is one of the largest $\mathrm{NH}_{3}$ emission hotspots of the world (Clarisse et al., 2009; Warner et al., 2016; Van Damme et al., 2014a, 2014b, 2018), and studies show about $\sim 400 \mathrm{kt} \mathrm{day}^{-1}$ of $\mathrm{NH}_{3}$ from rice-paddy and $\sim 70 \mathrm{kt} \mathrm{day}{ }^{-1}$ of $\mathrm{NH}_{3}$, $94,075 \mathrm{~kg} \mathrm{day}^{-1}$ from wheat residue (Casey et al., 2019). However, the emissions from south Asia are masked by enhanced levels of $\mathrm{SO}_{2}$ and $\mathrm{NO}_{\mathrm{X}}$, leading to additional aerosol load in the atmosphere (e.g. Warner et al., 2017). Sizable emissions of $\mathrm{NH}_{3}$ are also reported from other parts of the world from biomass burning, forest fires, and stubble burning. These include the studies from the Canadian wildfires (Lutsch et al., 2019), emissions from the continental United States (Bray et al., 2018; Adams et al., 2019) and from China (Wu et al., 2018; Chen et al., 2020). On top of these, the extreme cases such as El Nino could also trigger biomass burning and forest fires, as a study related to the $2015 \mathrm{El}$ Nino induced forest fires report 2-3 times higher (1.4-8.2 $\mathrm{Tg}$ of $\mathrm{NH}_{3}$ ) emissions than that of normal years (Whitburn et al., 2017).

Atmospheric $\mathrm{NH}_{3}$ is challenging to measure because of its high reactivity, solubility, and its stickiness to the measuring instruments. Furthermore, atmospheric $\mathrm{NH}_{3}$ exhibits large spatial and temporal variability. Several techniques have been used for measuring atmospheric concentrations of $\mathrm{NH}_{3}$ (e.g. Xu et al., 2018). In early years, passive samplers and spectroscopic methods were employed to measure atmospheric $\mathrm{NH}_{3}$. The temporal coverage was mostly daily for station and laboratory measurements. However, there are methods that are developed to provide high temporal coverage such as Quantum Cascade Laser absorption systems, Differential Optical Absorption Spectroscopy (DOAS) and Cavity-ring down spectroscopy (Ellis et al., 2011; Berden et al., 2000; Harren et al., 2012). The open path analyzers (OPA) are superior to all these methods as the OPA avoids the use of inlets, and thus interactions of $\mathrm{NH}_{3}$ with tubing, inlets, and filters are minimized (e.g. Sun et al., 2014). Promising results have also been obtained using Fourier Transform Infrared spectroscopy (FTIR) observations (Dammers et al., 2015). In addition, there are new spectroscopic measurements by mini-DOAS instruments in Switzerland and the Netherlands (e.g. Sintermann et al., 2016). Limited number of vertical profile of $\mathrm{NH}_{3}$ measurements is available from airborne measurements too (Nowak et al., 2010; Leen et al., 2013).

In the last decade, due to advances in satellite technology and retrieval algorithms, space-based measurements of $\mathrm{NH}_{3}$ have become possible. Currently, four different space instruments provide global coverage, with good spatial and temporal coverage of atmospheric $\mathrm{NH}_{3}$. These are the Atmospheric Infrared Sounder (AIRS: since 2002; Warner et al., 2016), the Infrared Atmospheric Sounding Interferometers (IASI: since 2006; Clarisse et al., 2009), the Cross-track Infrared Sounder (CriS: since 2011; Shephard and Cady-Pereira, 2015), and Thermal and Near infrared Sensor for carbon Observation-Fourier Transform Spectrometer (TANSO-FTS: since 2018; Someya et al., 2020). Although insitu measurements are site-specific, their temporal coverage is better than that of satellite measurements.

Studies dealing with $\mathrm{NH}_{3}$ emissions are mostly focused on their modeling and making their inventories (e.g. Paulot et al., 2014). The EDGAR (Emissions Database for Global Atmospheric Research) database is the most popular among the available $\mathrm{NH}_{3}$ inventories (Crippa et al., 2018). Liu et al. (2017) used satellite measurements and an atmospheric chemical transport model to estimate the rate of increase in $\mathrm{NH}_{3}(2.37 \%$ $\mathrm{yr}^{-1}$ ) over China between 2008 and 2014. The REAS (Regional Emission Inventory for Asia) $\mathrm{NH}_{3}$ data show a significant increase of about $0.17 \mathrm{~kg}$ $\mathrm{N} \mathrm{ha}^{-1} \mathrm{yr}^{-1}$ during the period 1980-2010 in Asia. In south Asia, agricultural activities have added about $21.3 \mathrm{Tg} \mathrm{N} \mathrm{yr}^{-1}$ to atmosphere, with an annual increase of about $0.3 \mathrm{Tg} \mathrm{yr}^{-1}$ in 1961-2014 (Xu et al., 2018). A large increase in $\mathrm{NH}_{3}$ with temperature is also observed from 13 years of AIRS measurements (Warner et al., 2016). Recent studies demonstrated that global atmospheric $\mathrm{NH}_{3}$ has increased with agricultural practices of soil nitrogen enrichment (e.g. urea application and its placement) and the underlying mechanism is governed by soil pH (Potter et al., 2003; Rochette et al., 2013; Warner et al., 2016).

According to the Food and Agricultural Organization (FAO), India is the second-largest producer of rice and wheat, which are mostly produced in Kharif (June-September, JJAS) and Rabi (October-February, ONDJF) seasons under the conventional farming practices using urea as a source of nitrogen. The hydrolyzed urea in soil may be emitted in the form of $\mathrm{NH}_{3}$ as a part of soil emissions. India and China together accounted for $64 \%$ of $\mathrm{NH}_{3}$ emissions in south Asia between 2000 and 2014 (Warner et al., 2016). There is also a rapid increase in allied agricultural activities such as livestock waste production in the last few decades in south Asia, which make the region as the largest hotspot of atmospheric $\mathrm{NH}_{3}$ (Zhang et al., 2010; Tian and Niu, 2015). Klimont (2001) predicts that the $\mathrm{NH}_{3}$ emissions from rice-paddy fields in the Kharif season will likely to be increased to $18.9 \mathrm{Tg} \mathrm{N} \mathrm{yr}^{-1}$ by 2030. In addition, as the fertilizer consumption is increasing in India (it increased at the rate of $2.79 \% \mathrm{yr}^{-1}$ in $2000-2014$ ), that would add a noticeable amount to $\mathrm{NH}_{3}$ emissions (Kumar and Indira, 2017).

There is a lack of detailed information about atmospheric $\mathrm{NH}_{3}$ in India. Although some studies (Banerjee et al., 2002; Gupta et al., 2003; Sharma et al., 2007; Datta et al., 2012) have reported site-specific analyses for $\mathrm{NH}_{3}$, those were limited to a few years. A dearth of analyses of atmospheric $\mathrm{NH}_{3}$ in seasonal and inter-annual scales further impede the understanding of soil nitrogen budget and policy-level decisions for soil fertility management.

Air quality is a very serious issue in India, and many of its cities are experiencing high levels of atmospheric pollution (e.g. State of Global Air Report, 2019: https://www.stateofglobalair.org/sites/default/files/ soga_2019_report.pdf,\%202019). The haze in Delhi and dust storms in the northern India are examples of these pollution episodes (Maji et al., 2018). Small suspended particles (PM - particulate matter) are dangerous pollutants and cause millions of premature deaths every year (David et al., 2019). Since atmospheric $\mathrm{NH}_{3}$ is converted to ammonium sulfates and nitrates, and contributes highly to atmospheric PM (Lachatre et al., 2019), the relatively high amount of atmospheric $\mathrm{NH}_{3}$ 
is a great threat to a clean atmosphere and ecosystems. Efforts have already been made globally to cut down the $\mathrm{NH}_{3}$ emissions and India is also a part of these missions (e.g. Paris Climate Summit) that aim at alleviating atmospheric emissions and global warming. Recently, India has also initiated a national programme for air pollution control (National Clean Air Programme, NCAP).

Here, we use the IASI satellite measurements to analyse the seasonal and inter-annual variability of atmospheric $\mathrm{NH}_{3}$ over India for the period 2008-2016. These measurements have been used in the past to delineate global industrial, agricultural, and natural $\mathrm{NH}_{3}$ hotspots (Van Damme et al., 2018; Clarisse et al., 2019a, 2019b). Detailed interseasonal and inter-annual analyses of atmospheric $\mathrm{NH}_{3}$ over India, however, have not been performed yet (Clarisse et al., 2009; Tanvir et al., 2019). Therefore, this study will be evaluating India's commitment and efforts to reduce atmospheric pollution, which makes it very important even for global pollution control initiatives, as this is the first detailed study on atmospheric $\mathrm{NH}_{3}$ over India.

\section{Data and methods}

\subsection{Ammonia from satellite measurements}

The IASI space-borne remote sensing instrument operates in the thermal infrared spectral range of $645-2760 \mathrm{~cm}^{-1}$. Its spectral resolution is $0.5 \mathrm{~cm}^{-1}$ with low noise of about $0.2 \mathrm{~K}$ at $950 \mathrm{~cm}^{-1}$ and $280 \mathrm{~K}$. The data used are derived from the IASI instrument on board MetopA, which was launched in 2006 in a polar sun-synchronous orbit with mean local solar overpass time of 9:30 am and 9:30 pm (Clerbaux et al., 2009). It covers the globe twice a day with a good horizontal coverage due to its ability to scan across the swath. Each observation is composed of 4 pixels with a circular footprint of $12 \mathrm{~km}$ diameter at nadir $(20 \times 39 \mathrm{~km}$ elliptical at the end of the swath). We have used the 9.30 am measurements, as the relative errors are larger for the night-time measurements owing to the lower thermal contrast for the 9. $30 \mathrm{pm}$ overpass. The IASI- $\mathrm{NH}_{3}$ data show fair agreement with monthly- integrated ground-based measurements (Van Damme et al., 2015). First validation has been achieved by comparing IASI-NH3 column measurements with FTIR column data (Dammers et al., 2015). IASI measurements are also consistent with other $\mathrm{NH}_{3}$ satellite products (e.g., Clarisse et al., 2010; Someya et al., 2020; Viatte et al., 2020).

IASI, with its long data record and well suited instrumental specifications to measure $\mathrm{NH}_{3}$, allows studying a region such as India, where a range of $\mathrm{NH}_{3}$ concentrations is present (from close to zero to the largest hotspot of the world) across the latitudes $\left(8^{\circ}-38^{\circ} \mathrm{N}\right)$. The long-term $\mathrm{NH}_{3}$ measurements from IASI facilitate meaningful statistical analyses on the inter-annual variability and trend estimates. The IASI measurements were used in the past for creating the first global atmospheric $\mathrm{NH}_{3}$ map (Clarisse et al., 2009), and retrieval algorithms have been continuously improved since then. An improved retrieval scheme for IASI spectra was presented in Van Damme et al. (2017) and Whitburn et al. (2016a, 2016b), and it relies on the calculation of a dimensionless "Hyperspectral Range Index," which is subsequently converted to the total column. A detailed inventory of $\mathrm{NH}_{3}$ hotspots using a decade of IASI $\mathrm{NH}_{3}$ measurements is provided in Van Damme et al. (2018). Clarisse et al. (2019a, 2019b) have presented a wind-adjusted superresolution technique to allow a better identification of weak point sources of atmospheric $\mathrm{NH}_{3}$. We have considered the reanalyzed $\mathrm{NH}_{3}$ total column data (ANNI-NH3-V2.2R-I) (Whitburn et al., 2016a, 2016b; Van Damme et al., 2017). The daily retrieved columns were averaged for each month, seasons and individual years. The trends in atmospheric $\mathrm{NH}_{3}$ are computed from its anomaly (individual year/ season subtracted from its climatology for the study period) and then divided by the climatology. These trend values are then multiplied by 100 to represent them in percent. Statistically significant (at the $95 \%$ confidence interval) trend values are described as "significant" throughout the article.
2.2. Particulate matter, population, fertilizer, fire count, and meteorological data

The particulate matter (PM) data were taken from the National Air Quality Monitoring Programme (NAMP) of Central Pollution Control Board ( $\mathrm{CPCB}$ ) under national data sharing and accessibility policy. The data contain the location-wise summary of $\mathrm{PM}_{10}$ having an aerodynamic diameter less than or equal to $10 \mu \mathrm{m}$. These data were georeferenced and interpolated using the Kriging method available on the ArcGIS software. The annual and seasonal mean concentrations were expressed as micrograms per cubic meter area. The state-wise $\mathrm{PM}_{10}$ data were taken from the open data platform of India government. Gridded rainfall data from IMD (India Meteorological Department) for the period 2008-2015 were considered to examine the wet deposition of ammonia. Temperature data of IMD were used from 2008 to 2015 to test the dependency of $\mathrm{NH}_{3}$ on temperature. Total fertilizer consumption data for the period 2008-2016 were taken from the fertilizer association of India to find the correlation between total fertilizer consumption and atmospheric $\mathrm{NH}_{3}$ concentrations.

The MODerate resolution Imaging Spectrometer (MODIS) on board Terra and Aqua satellites provides fire count information based on radiance measurements at two mid-infrared bands: 4 and $11 \mu \mathrm{m}$ (Friedl et al., 2002). We have considered the cloud corrected fire count data of the MODIS Terra and Aqua over 2008-2016 on a spatial resolution of $0.5^{\circ} \mathrm{X} 0.5^{\circ}$ to study the relationship between biomass burning and $\mathrm{NH}_{3}$ emissions. Gridded relative humidity ( $\mathrm{RH}$ ), wind and cloud cover data from ERA-Interim for the period 2008-2016 were used to assess the impact of meteorological parameters on $\mathrm{NH}_{3}$ emissions (Dee et al., 2011). We have also analysed the Indian Population Census 2011 data (e.g. Saikia et al., 2016) to find the influence of socio-economic and demographic factors on $\mathrm{NH}_{3}$ emissions.

\subsection{Seasonal changes in atmospheric ammonia}

Fig. 1 shows the distribution of atmospheric $\mathrm{NH}_{3}$ during summer season (monsoon, Kharif or JJAS) averaged for the period 2008-2016 (right) and the land use land cover (LULC) pattern of India (left). The regions with croplands are shown in orange and are spread across India. The analyses show the largest $\mathrm{NH}_{3}$ concentrations over IGP (Fig. S1 shows the study regions), about $\geq 6 \times 10^{16} \mathrm{~mol} \mathrm{~cm}^{-2}$, as the region is highly cultivated. In addition, the regions with higher $\mathrm{NH}_{3}$ emissions are mainly croplands; indicating that the agricultural activities are one of the major sources of atmospheric $\mathrm{NH}_{3}$ in India. For instance, very small $\mathrm{NH}_{3}$ columns $\left(0-1 \times 10^{16} \mathrm{~mol} \mathrm{~cm}^{-2}\right)$ are observed at the iceclad and barren regions of Kashmir and Arunachal Pradesh (northeast India). The concentrations are about $1-3 \times 10^{16} \mathrm{~mol} \mathrm{~cm}{ }^{2}$ in the peninsular region (south India) and it increases to $3-5 \times 10^{16} \mathrm{~mol} \mathrm{~cm}^{-2}$ in the central and northwest India, where the arable lands undergo seasonal agricultural activities.

There is large seasonal variability in atmospheric $\mathrm{NH}_{3}$ concentrations (Fig. 2) over India. The largest concentration is found in the monsoon season, where values $\geq 6 \times 10^{16} \mathrm{~mol} \mathrm{~cm}^{-2}$ are found in the IGP, which has the highest number of urea fertilizer plants in India (e. g. as shown in Fig. 1, Indian Fertilizer Scenario 2015). In the central and northwest India the $\mathrm{NH}_{3}$ concentrations are about $3-5 \times 10^{16} \mathrm{~mol}$ $\mathrm{cm}^{-2}$, but are not very high in other parts of India $\left(<3 \times 10^{16} \mathrm{~mol}\right.$ $\mathrm{cm}^{-2}$ ). Therefore, the seasonal changes are highest in IGP, northwest and central Indian regions, whereas the lowest $\mathrm{NH}_{3}$ columns are found in autumn and winter. The average column values of about 3-4 $\times 10^{16} \mathrm{~mol} \mathrm{~cm}^{-2}$ found in the Himalaya region in spring are connected to the agricultural activities there. For example, the crop production months of Kharif season show very high $\mathrm{NH}_{3}$ values in the alluvial plain areas (i.e. IGP). The agriculture intensive states Punjab and Haryana show the peak concentrations of atmospheric $\mathrm{NH}_{3}$, about $10-13 \times$ $10^{16} \mathrm{~mol} \mathrm{~cm}{ }^{-2}$. However, there is a reduction in the $\mathrm{NH}_{3}$ values from the end of Kharif season to the start of Rabi season, and this could be 


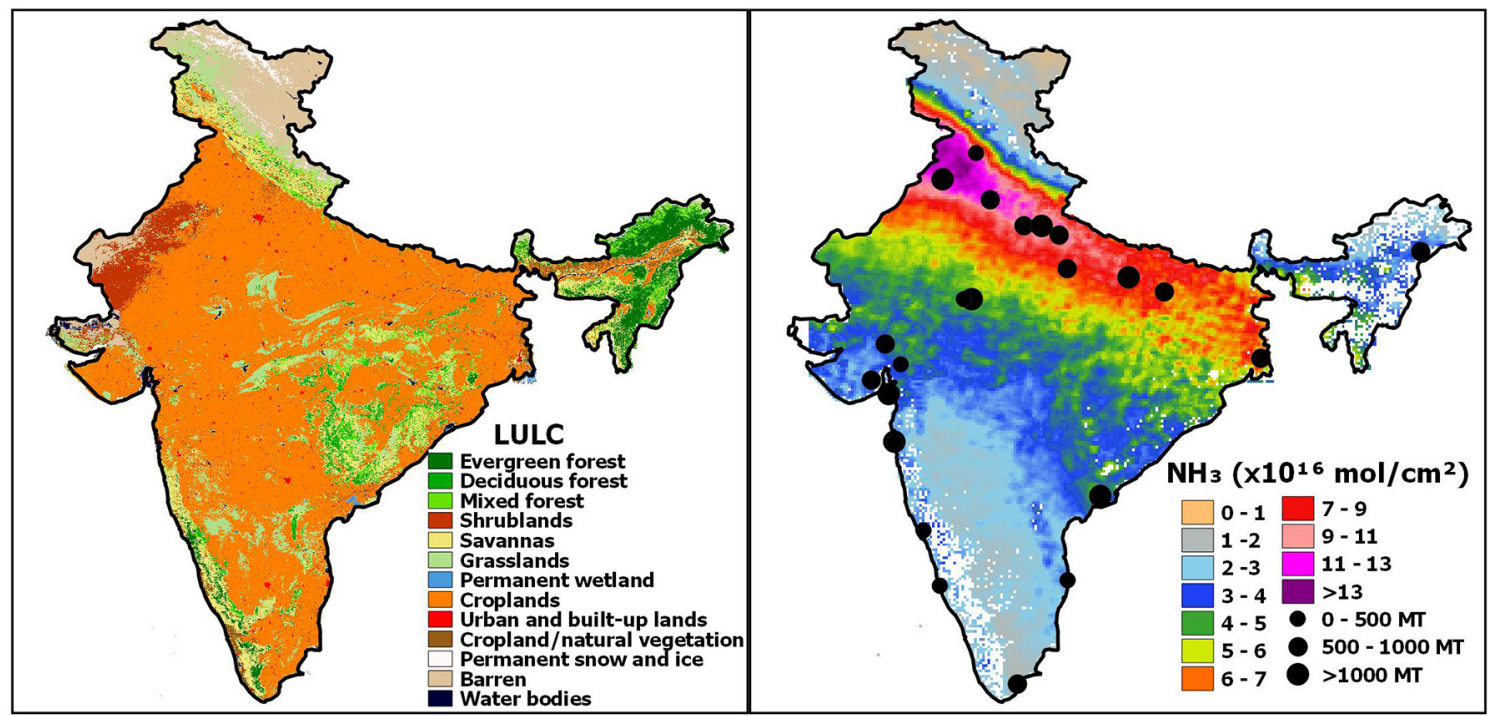

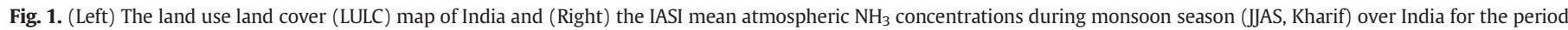
2008-2016 $\left(\mathrm{mol} \mathrm{cm}^{-2}\right)$. The average production of urea in various fertilizer plants in India from 2008 to 2013 is also shown in black filled-circles.

due to the wet deposition during rainy days and gas to particle conversion under cold weather conditions during the period. Our analysis shows the highest atmospheric $\mathrm{NH}_{3}\left(4 \times 10^{16} \mathrm{~mol} \mathrm{~cm}^{-2}\right)$ during monsoon followed by MAM $\left(3 \times 10^{16} \mathrm{~mol} \mathrm{~cm}{ }^{-2}\right)$, which is in agreement with the higher $\mathrm{NH}_{3}$ emissions in the Kharif season. The higher values of $\mathrm{NH}_{3}$ in monsoon season can be attributed to the decay and decomposition of stubble, vegetation and other organismic remains in hot and humid Indian summer monsoon (Singh and Kulshrestha, 2012; Van Damme et al., 2014a, 2014b; Tang et al., 2018). The fertilizer application is also highest during this period. Nevertheless, the $\mathrm{NH}_{3}$ concentration is marginally reduced during post-monsoon to $2 \times 10^{16} \mathrm{~mol} \mathrm{~cm}^{-2}$ due to the soil saturation and crop maturation period of Kharif crops. According to the Food and Agriculture organization report 2005 (http:// www.fao.org/3/a0257e/a0257e05.htm) paddy is the most important Kharif crop in India in terms of both area and fertilizer consumption. Occupying an area of 44.7 million ha, it accounted for 32\% (5.34 million tonnes) of total fertilizer consumption in 2003-2004. This is clearly related to the characteristics of Kharif crops, as they mostly comprise cereals that require frequent application of nitrogen fertilizers such as urea in heavy doses until the flowering stage; from mid-August to early-October (i.e. during monsoon). Li et al. (2017) also show the largest $\mathrm{NH}_{3}$ concentration in summer and smallest in winter with the measurements made using passive samplers at the urban and agriculture sites of northern Colorado in the United States.

Since IGP exhibits the largest total columns of $\mathrm{NH}_{3}$ over India, we closely examine the averaged atmospheric $\mathrm{NH}_{3}$ at six different agriculture intensive regions in India (Fig. 3 top panel): Peninsular, Central, North West, North East, Hilly and IGP regions. The monthly mean data show a gradual increase in atmospheric $\mathrm{NH}_{3}$ from January to July and then a slow decrease thereafter. Since the $\mathrm{NH}_{3}$ concentrations are very small in the peninsular region, and high rainfall during monsoon period, the monthly distribution has no detectable peak during the JJAS period as for the other regions. The analyses show $\mathrm{NH}_{3}$ values smaller than $2 \times$ $10^{16} \mathrm{~mol} \mathrm{~cm}^{-2}$ in the Peninsular region with a peak in May due to high temperature that aids volatilization, and $2-3 \times 10^{16} \mathrm{~mol} \mathrm{~cm}^{-2}$ in the central India, 2-6 $\times 10^{16} \mathrm{~mol} \mathrm{~cm}^{-2}$ in the northwest India, and about $1.8-5.6 \times 10^{16} \mathrm{~mol} \mathrm{~cm}^{-2}$ for the all India average. However, the total columns at IGP are twice as large as in the northwest and that of all India average. It is about $3 \times 10^{16} \mathrm{~mol} \mathrm{~cm}^{-2}$ in January and gradually increased to $7.2 \times 10^{16} \mathrm{~mol} \mathrm{~cm}^{-2}$ in May with a peak of $11.5 \times 10^{16} \mathrm{~mol}$ $\mathrm{cm}^{-2}$ in July. The concentrations again decrease to $8.2 \times 10^{16} \mathrm{~mol}$ $\mathrm{cm}^{-2}$ in August and then to $2.5 \times 10^{16} \mathrm{~mol} \mathrm{~cm}^{-2}$ in December.
In India, the common Kharif crops are rice, sugarcane, maize and millets, and are mostly cultivated in the north and northwestern region, and they produce higher emissions of $\mathrm{NH}_{3}$ in the Kharif season. Similarly, paddy is the main crop of the northwestern and eastern regions, and high volatilization of $\mathrm{NH}_{3}$ from paddy fields lead to higher concentrations of $\mathrm{NH}_{3}$ in these regions. The Zaid (March-May) season shows high variability of $\mathrm{NH}_{3}$ over IGP (after the Kharif season) due to the saturated soils and relatively lower temperatures during the Rabi season. In addition, Zaid crops are grown in the pre-monsoon period and are mostly cultivated by using own farm irrigation, but it is rarely practiced as rain-fed farming dominates agriculture in India. Therefore, most farmlands stay fallow in this season, which leads to smaller atmospheric $\mathrm{NH}_{3}$ concentrations during pre-monsoon. The Rabi season crops are winter crops that are cultivated between October and February, and show lower $\mathrm{NH}_{3}$ values because of the wet deposition of $\mathrm{NH}_{3}$ during the monsoon rainfall, as reported by the high $\mathrm{NH}_{4}^{+}$in the precipitation over Indian region (Kulshrestha et al., 2005; Warner et al., 2016). The recommended practice of rotating cereals with legumes in predominant cereal-legume cropping sequence and comparatively low nitrogen required in cereal-cereal cropping sequence in Rabi season further cut the $\mathrm{NH}_{3}$ emission at the source. Additionally, low temperatures and soil moisture help gas to particle conversion, as evident from the higher concentration of $\mathrm{PM}_{10}$ (Fig. S2) in Rabi season.

Apart from these, biomass burning contributes significantly to $\mathrm{NH}_{3}$ emissions, second after agriculture. Fig. 3 (bottom panel) shows the fire counts, as a proxy for biomass burning, for different regions over India. The analyses show no significant fire events in Hilly, Peninsular, Northwest and Central Indian regions, where the $\mathrm{NH}_{3}$ concentrations are also relatively smaller. However, the northeast regions show numerous fire events in spring and are largest among the regions and seasons (e.g. 1.1 counts in March). On the other hand, IGP shows a double peak ( 0.4 in May and 0.34 in October) in fire counts in its annual cycle corresponding to the two major harvest seasons, Kharif and Rabi, respectively. This can also be due to the substantially high temperature that reduces soil moisture and increases soil temperature to trigger a pulse in the emission in summer months (Parashar et al., 1998; Fan et al., 2011), followed by the emissions connected to episodic rain events in a long dry period in October (Roelle and Aneja, 2002). However, because of the relatively smaller time window for the sowing of Rabi crops after the Kharif-harvest, burning of stubbles can be another reason for this peak in October. Therefore, these fire counts indicate that in addition to the intense agriculture in Kharif and modest farming in Rabi, 


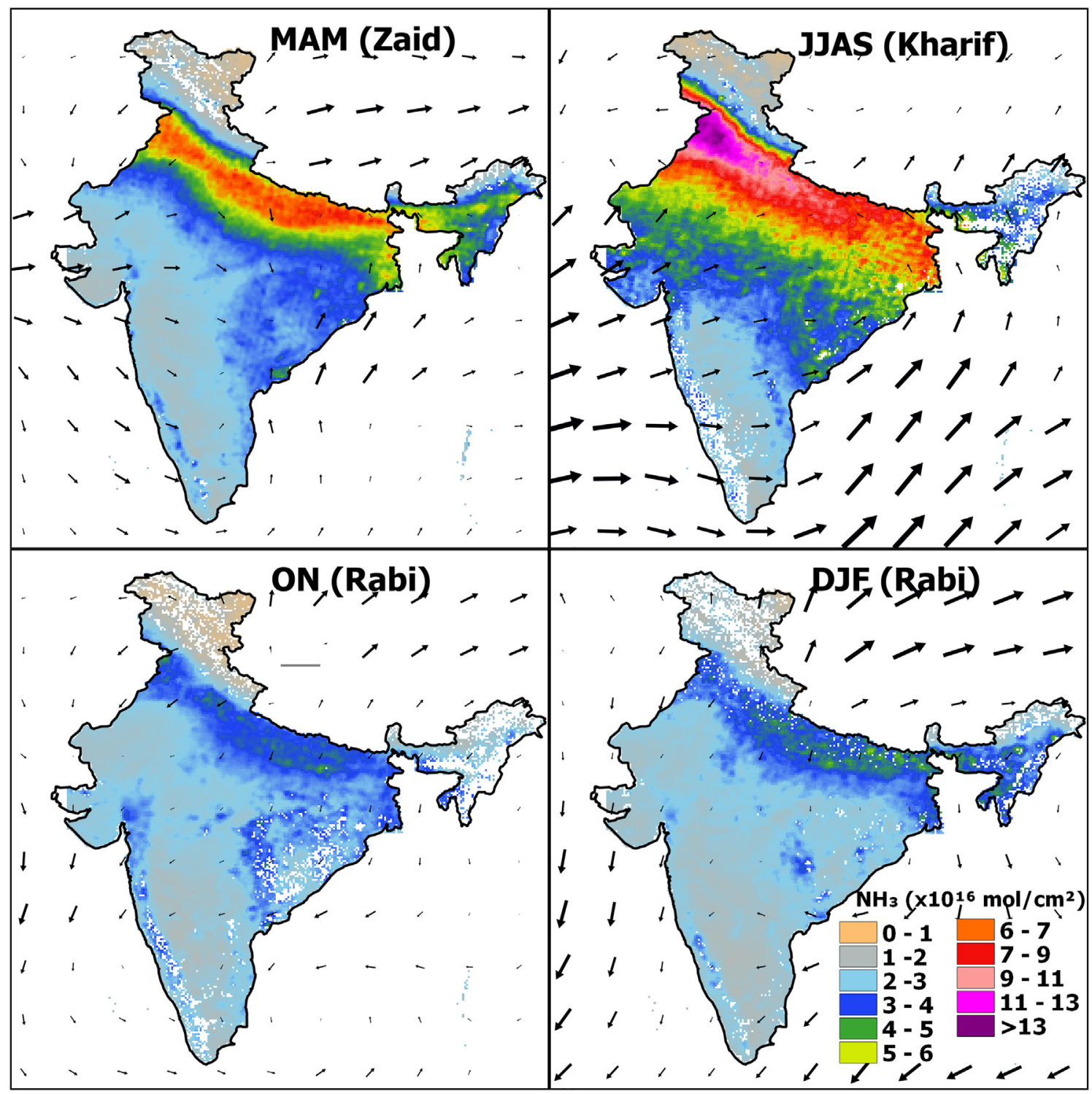

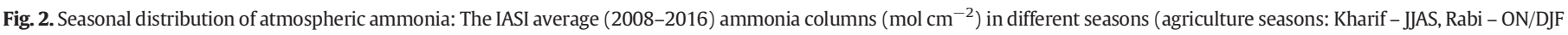

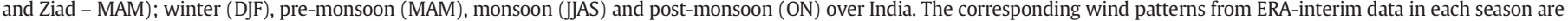
overlaid.

the biomass burning (including forest fires and stubble burning) significantly contributes to the $\mathrm{NH}_{3}$ concentration over IGP and Northeast. However, the peaks appear in February-March in the peninsular region are consistent with the major harvest season there (Venkataraman et al., 2006). These results are in very good agreement with those of Tanvir et al. (2019), who analysed atmospheric $\mathrm{NH}_{3}$ over south Asia for the period 2004-2014, and showed very high atmospheric $\mathrm{NH}_{3}$ emissions there. As expected, the seasonal changes in the $\mathrm{NH}_{3}$ concentration is larger than their changes in individual months, which is consistent with the findings of other studies (Singh and Kulshrestha, 2012; Warner et al., 2016; Liu et al., 2017; Tang et al., 2018).

The analyses (Figs. 1 and 2) clearly show that the largest $\mathrm{NH}_{3}$ concentrations are in Punjab and Haryana; the north-western states of India. These states have two major agricultural seasons Kharif and Rabi, with rice as a major crop during the Kharif season (e.g. Upadhyay et al., 2008). These are also among the top agricultural production states in India (Kharif crops in particular) and they have a number of fertilizer production units owing to high rate of fertilizer consumption. This is also justified by the available data that show an overall increase in the nitrogen fertilizer consumption since 2004 (shown in Fig. S3) and as shown by Blaurock-Busch et al. (2014). This situation probably has created an interesting soil environment in these regions, as the intense fertilizer application has altered the $\mathrm{pH}$ of these soils. The release of $\mathrm{NH}_{3}$ through volatilization from alkaline soils is well documented, particularly under cereal crops, and is an important pathway of nitrogen loss in agricultural soils (Bouwman et al., 2002). Additionally, the $\mathrm{NH}_{3}$ emission intensifies when the soil $\mathrm{pH}$ is around 8, particularly in higher temperature conditions, such as in summer months (Fan et al., 2011). Sharma et al. (2016) have reported that $\sim 54 \%$ of total soil area in Punjab has an average $\mathrm{pH}$ around 8.1 and Fan et al. (2011) estimated an increase of 1.7 fold in ammonia emissions from alkaline soils under high soil temperatures. These findings further substantiate our assessment of Punjab and Haryana being the largest $\mathrm{NH}_{3}$ emitter regions in India due to their alkaline soil and higher temperatures even during summer monsoon season.

\subsection{Inter-annual variability in atmospheric ammonia}

The inter-annual variability of $\mathrm{NH}_{3}$ depends on the meteorology and agricultural practices such as crop types and fertilizer consumption (e.g. 

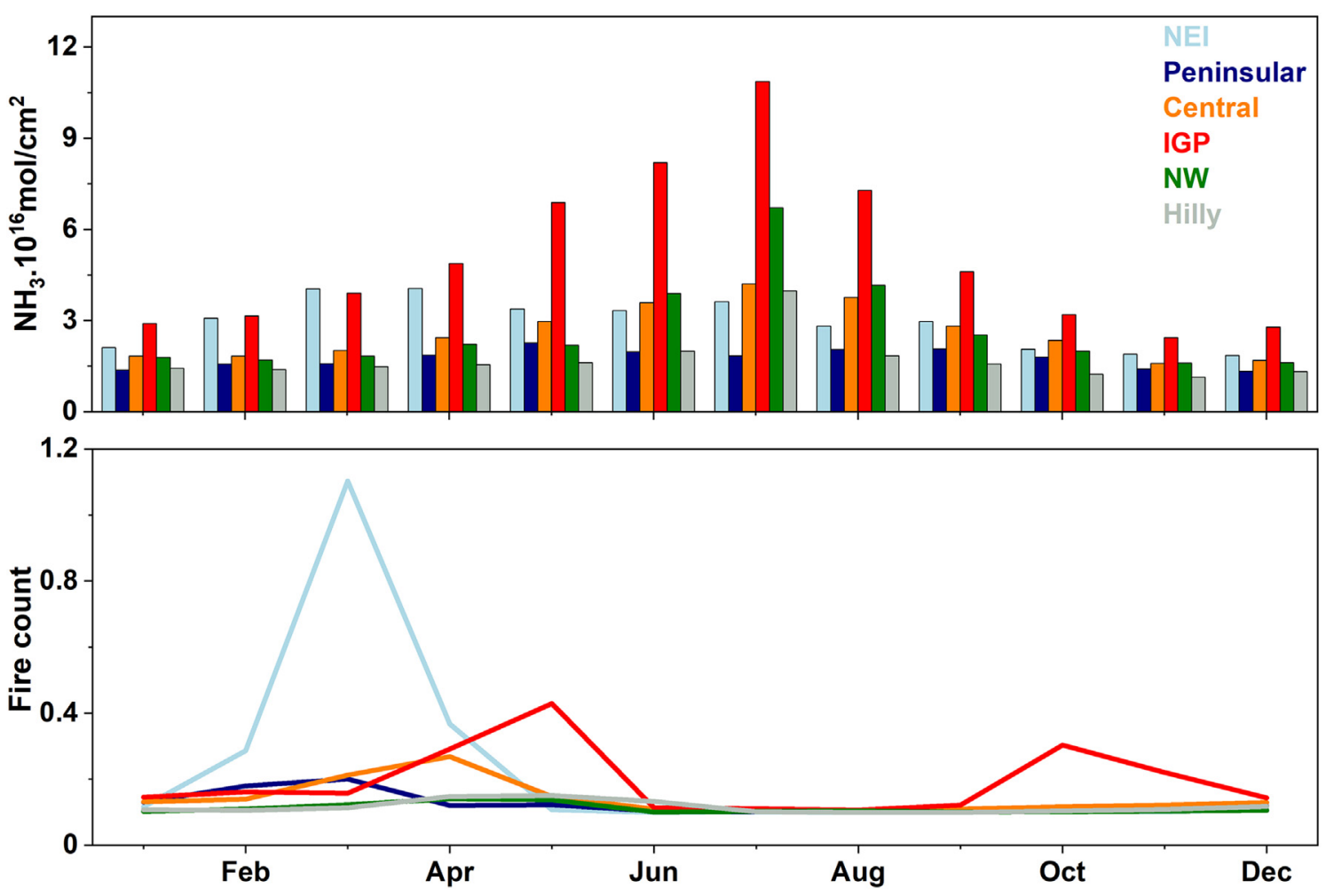

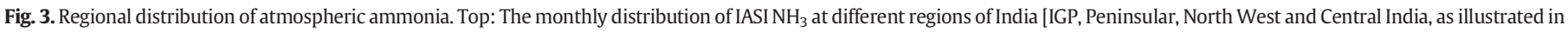
Fig. S1]. The data are averaged from 2008 to 2016. Bottom: The MODIS satellite measurements of fire counts in the respective each regions.

Viatte et al., 2020). When compared to the 9-year (2008-16) average $\mathrm{NH}_{3}$ concentration, the highest annual $\mathrm{NH}_{3}$ concentration is observed in the year 2010, which is about $4 \%$ higher than that of other years. This is very likely due to the highest annual total fertilizer consumption in that year (Fig. 4). The total annual fertilizer consumption in 2010 is increased by $7 \%$ as compared to the 9 -year average total fertilizer consumption. Meteorological conditions also favor the highest $\mathrm{NH}_{3}$ concentration in 2010, as the mean temperature of 2010 is comparatively higher than all other years (Fig. S4). In contrast, the lowest annual $\mathrm{NH}_{3}$ concentration is observed in 2013 and is about 5\% smaller than its 9-year average. The drop in $\mathrm{NH}_{3}$ concentration in 2013 is likely due to the reduction in annual total fertilizer consumption (6.48\%) and the higher annual rainfall (helps scavenging of $\mathrm{NH}_{3}$ ) in that year.

\subsection{Impact of meteorological factors}

As our objective is to analyse the seasonal and inter-annual changes in $\mathrm{NH}_{3}$ in the atmosphere in response to agriculture and allied industries, we estimate the seasonal and long-term trends in $\mathrm{NH}_{3}$ over India. Fig. 5 shows the $\mathrm{NH}_{3}$ together with temperature, precipitation, winds, $\mathrm{RH}$, and cloud cover in JJAS, in which the largest amounts of atmospheric $\mathrm{NH}_{3}$ are found over India and IGP. It can be seen that the $\mathrm{NH}_{3}$ values are very small over the regions with high precipitation (e.g. Western Ghats and northeast, Nair et al., 2018) and lower temperatures (e.g. southwest India and northeast) due to wet deposition. The RH and cloud cover are also higher at these regions owing to the monsoon. The moderate rainfall region (about $300 \mathrm{~mm}$ ) with higher temperature (28 ${ }^{\circ} \mathrm{C}$ ) and $80-90 \%$ cloud cover (e.g. north India, except IGP) coincides with the moderate levels of $\mathrm{NH}_{3}$, about $3-9 \times 10^{16} \mathrm{~mol} \mathrm{~cm}^{-2}$. Similarly, the lower temperature $\left(0-10{ }^{\circ} \mathrm{C}\right)$, small precipitation $(10 \mathrm{~mm})$, sparse clouds (about 50\%) areas have smaller values of atmospheric $\mathrm{NH}_{3}$ in those barren lands, about $0-2 \times 10^{16} \mathrm{~mol} \mathrm{~cm}^{-2}$. Although higher temperature aids volatilization of atmospheric $\mathrm{NH}_{3}$, IGP with higher temperatures $\left(30-32{ }^{\circ} \mathrm{C}\right)$ still shows higher values of $\mathrm{NH}_{3}$, as the production of
$\mathrm{NH}_{3}$ from croplands and numerous fertilizer plants outweigh the influence of local meteorological factors. In addition, the higher temperatures in the region are also weighted by many cities in the IGP region (e.g. Raj et al., 2020). We have done similar analyses for all seasons, and are shown in Fig. S5. The $\mathrm{NH}_{3}$ concentrations are very small in the Rabi season and the meteorology with sparse precipitation, lower temperatures and fewer clouds are also not favorable for $\mathrm{NH}_{3}$ production, except that emitted by the Rabi cropping system. On the other hand, the temperature is higher in spring and moderate rainfall facilitate cropping in Zaid and thus makes appreciable $\mathrm{NH}_{3}$ emissions. In short, in addition to the agriculture and allied industries, local meteorology also influences the distribution of $\mathrm{NH}_{3}$ in the atmosphere (Fig. S6-S9 shows the distribution of atmospheric $\mathrm{NH}_{3}$ in other years and seasons).

\subsection{Impact of socio-economic factors}

The socio-economic factors and their influence on atmospheric $\mathrm{NH}_{3}$ are diagnosed with correlation analyses with individual parameters. A correlative rose diagram of the relationship between $\mathrm{NH}_{3}$ and different meteorological and socio-economic factors is displayed in Fig. 6. The $\mathrm{NH}_{3}$ concentrations show a good correlation with fertilizer consumption (about 0.75 ) and population (0.7), and anti-correlation with precipitation (from -0.2 to -0.8 ). It suggests that regions with higher population and fertilizer consumption have higher $\mathrm{NH}_{3}$ emissions. Most of the compound as well as straight fertilizers have ammonium-nitrogen content, which justifies its high correlation with $\mathrm{NH}_{3}$. The correlation with population (2011 census of India) shows a coefficient of 0.7 due to the emissions from landfills of household wastes. Furthermore, the higher population is connected to fertilizer driven enhanced food production and more household waste production (e.g. Lou et al., 2015) and even human excreta (e.g. Chang et al., 2015), which would emit $\mathrm{NH}_{3}$ to the atmosphere. The population and fertilizer data are annual average as there are no seasonal data. 


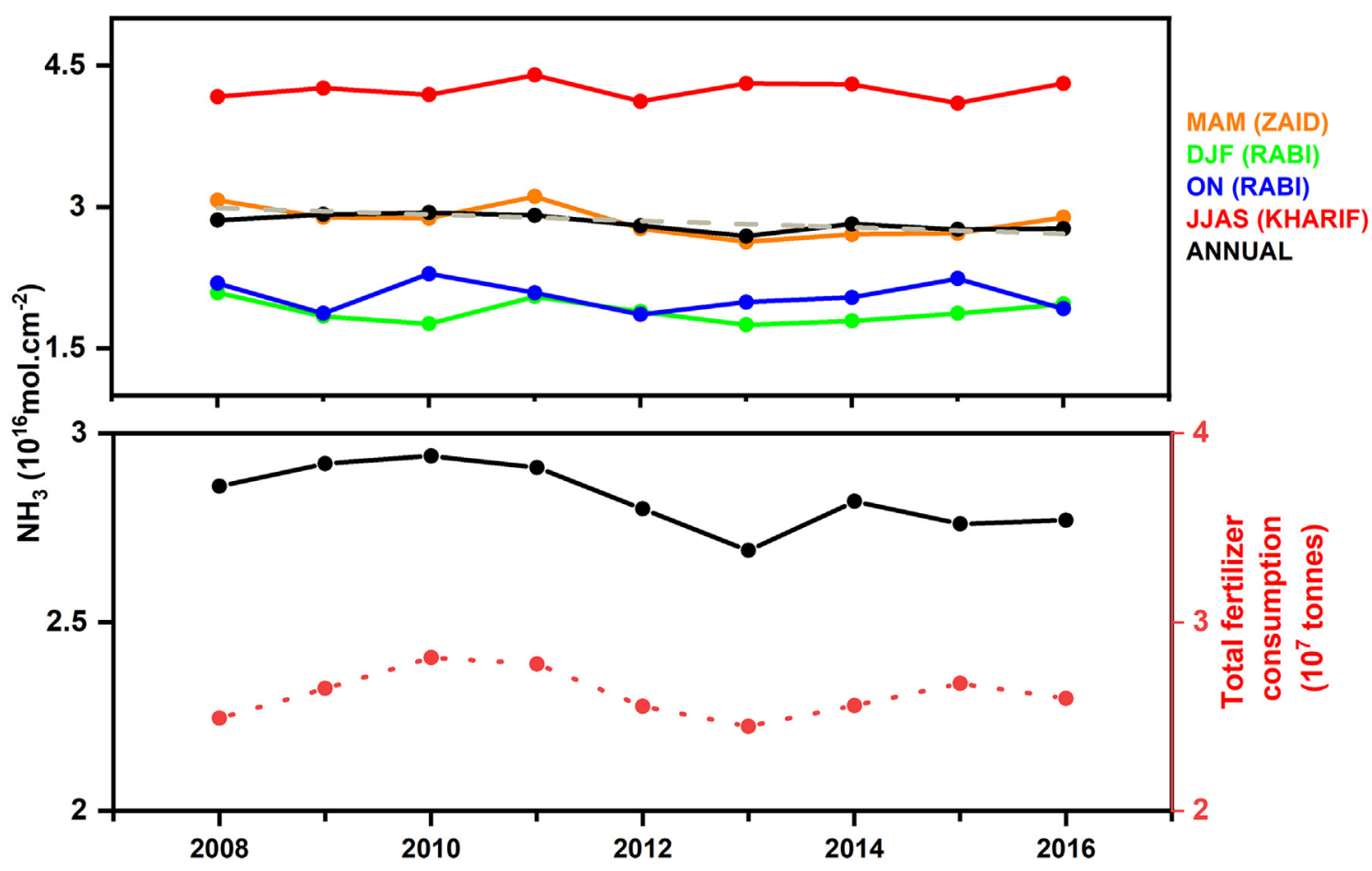

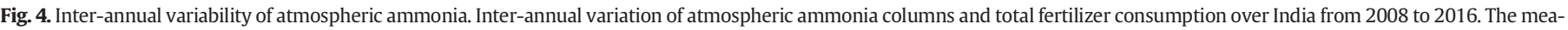

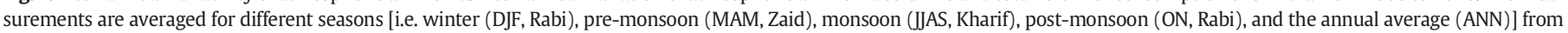
year 2008 to 2016.

The wet deposition during precipitation makes an anti-correlation between precipitation and atmospheric $\mathrm{NH}_{3}$, which is more effective in Rabi season, about -0.80 , and that for other seasons are about -0.2 to -0.4 . Higher temperature helps volatilization of atmospheric $\mathrm{NH}_{3}$ and therefore, a correlation of $0.4-0.5$ is estimated. The connection between $\mathrm{RH}$ is not very strong in any season as displayed by the correlation analyses. However, it has to be noted that RH plays an important role in gas to particle conversion, and therefore, indirectly affects $\mathrm{NH}_{3}$ concentration. The higher $\mathrm{RH}$ increases volatilization in higher temperatures too, which is why a reasonable correlation of 0.3 is estimated, and likewise, the increased cloud cover suppresses the atmospheric emissions.

The biomass burning contributes significantly to the $\mathrm{NH}_{3}$ emissions, and is evidenced by a correlation of about $0.2-0.3$ with the fire counts. It is largest in MAM that includes the biomass and stubble burning months. There is a direct relationship between $\mathrm{NH}_{3}$ and particulates as the conversion of $\mathrm{NH}_{3}$ produces PM, as suggested by a correlation coefficient of 0.65 . Ammonia present in the atmosphere reacts with nitric acid and sulfuric acid, and forms, in turn, ammonium nitrate $\left(\mathrm{NH}_{4} \mathrm{NO}_{3}\right)$ and ammonium sulfate $\left(\left(\mathrm{NH}_{4}\right)_{2} \mathrm{SO}_{4}\right)$ that help the formation of PM (both $\mathrm{PM}_{10}$ and $\mathrm{PM}_{2.5}$ ) (Gong et al., 2013). The inter-seasonal and inter-annual variability of $\mathrm{PM}_{10}$ are presented in the supplementary information (Figs. S10 and S11). We examined the connection between $\mathrm{NH}_{3}$ and $\mathrm{PM}_{10}$ with a spatial correlation analysis for the period 2008-2015 over the Indian region (Fig. S12), and there is a high correlation between them $(r=0.5-1.0)$, particularly in the IGP and northwestern regions. Our results are also in agreement with that of Viatte et al. (2020), as they show that $\mathrm{NH}_{3}$ plays a key role in the formation of secondary aerosols over Paris and surroundings.

We have done a separate analysis for IGP and the coefficients are also similar for fertilizer consumption, population, $\mathrm{RH}$, fire count, $\mathrm{PM}_{10}$, and temperature. However, since IGP has the largest atmospheric $\mathrm{NH}_{3}$ over India, the conversion to PM shows slightly higher correlation value, but lower wet deposition due to the relatively smaller rainfall received in that region during the period. These results suggest that the meteorological factors such as temperature and precipitation have good control over atmospheric concentration of $\mathrm{NH}_{3}$ and its seasonal variability and transport. Nevertheless, except during monsoon, all other seasons have lower $\mathrm{NH}_{3}$ concentrations and smaller inter-annual variability.

\subsection{Trends in atmospheric ammonia over India}

We have estimated trends in atmospheric $\mathrm{NH}_{3}$ to assess the temporal changes in agricultural activities in India during 2008-2016 and are shown in Fig. 7. The trends are estimated for each region, season and for annual average (as shown in Fig. 4). In general, the ammonia averaged over all India shows an insignificant positive trend in JJAS $(0.08 \%$ $\mathrm{yr}^{-1}$ ), insignificant negative trends in ON and DJF (around $-0.5 \%$ $\left.\mathrm{yr}^{-1}\right)$, and significant negative trends $\left(-1.2 \% \mathrm{yr}^{-1}\right)$ in MAM for the annual average data $\left(-0.8 \% \mathrm{yr}^{-1}\right)$. However, the trends computed for the largest ammonia hotspot of India, IGP, is slightly different, as it shows insignificant trends in all seasons and for the annual average. The estimated trends are positive in JJAS and DJF (about $1 \% \mathrm{yr}^{-1}$ ) and are negative in other seasons and annual mean data $\left(-0.9 \% \mathrm{yr}^{-1}\right.$ in $\mathrm{ON}$, $-0.7 \% \mathrm{yr}^{-1}$ in MAM, and $-0.5 \% \mathrm{yr}^{-1}$ for the annual average) at IGP. The trends estimated for all other Indian regions combined, except IGP, reveal significant negative trends in all seasons $\left(-1.5 \% \mathrm{yr}^{-1}\right.$ in MAM, and about $-1 \% \mathrm{yr}^{-1}$ in other seasons and annual average), except in JJAS $\left(+1 \% \mathrm{yr}^{-1}\right)$, as for IGP and all India average.

Since the trends discussed above are regional averages that suppress many local features of agriculture and industrial activities, we have also estimated the satellite pixel-wise spatial trends for the whole India to expose regional hotspots in terms of their significance. Therefore, slightly higher trend values, even up to $\pm 10 \% \mathrm{yr}^{-1}$ are estimated in some regions such as the northwest and southeast India. Note that the information regarding the statistical significance with only a range of values (e.g. from 0 to $\pm 10 \% \mathrm{yr}^{-1}$ ) is presented in Fig. 7, but a detailed discussion is presented herein. For instance, significant positive trends of about $2.5 \%-9.5 \% \mathrm{yr}^{-1}$ are estimated in the northwest and lower IGP regions in winter (DJF). The trends are negative and insignificant in other regions. However, the negative trends (from $-2.4 \%$ to $-7.5 \%$ 


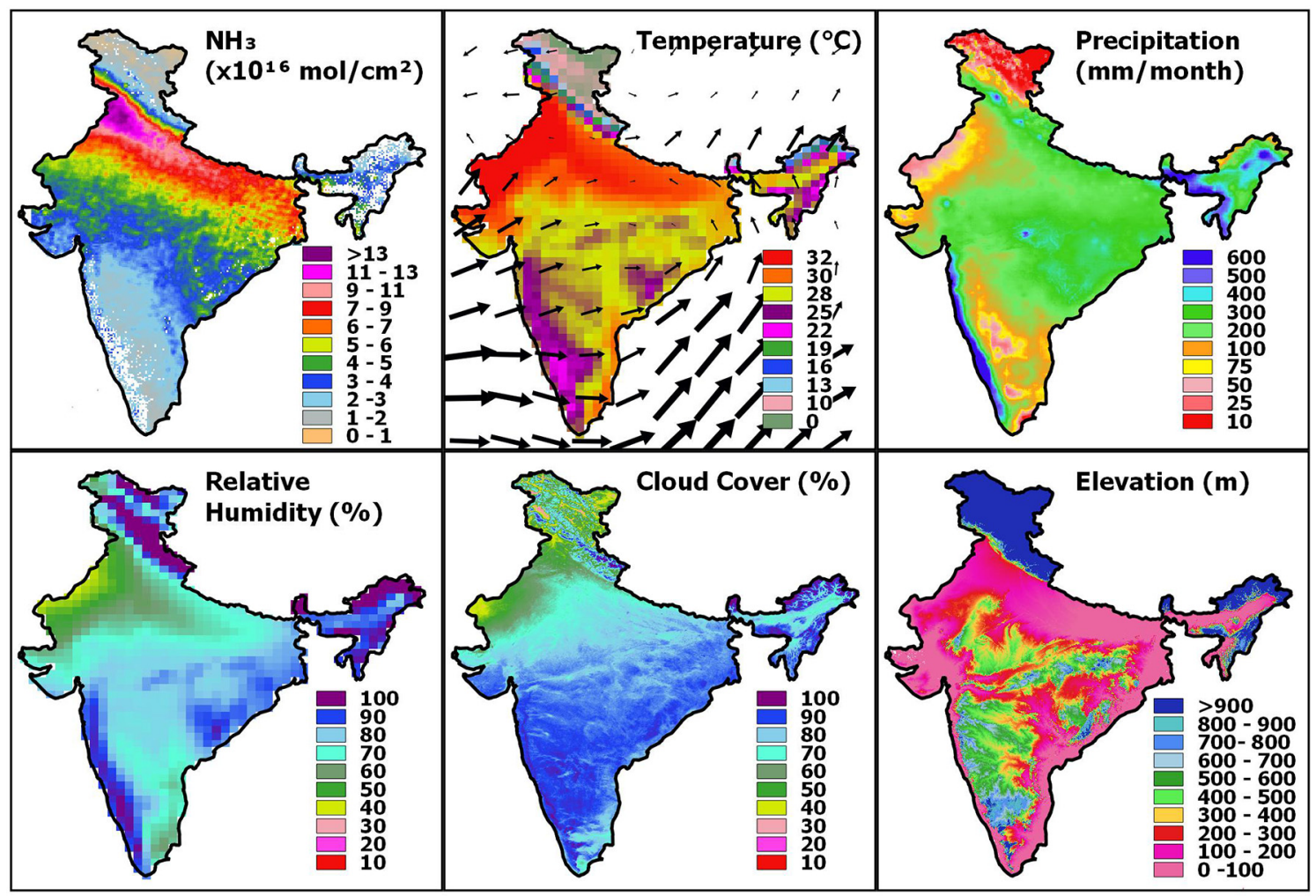

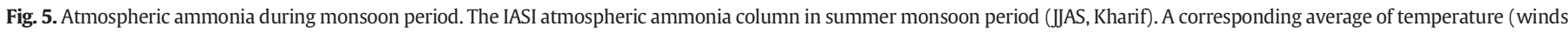
overlaid), precipitation, relative humidity, cloud cover, and topography or elevation from ERA-Interim data are presented. All data are averaged over the period $2008-2016$.

$\mathrm{yr}^{-1}$ ) are significant in the south Indian regions of Telangana and some parts of Karnataka, Maharashtra and Andhra (e.g. see Fig. S13 for information on states) during winter as the cereal-fallow/legumes/oilseeds cropping sequence being widely practiced in the Kharif-Rabi cropping cycle. In spring (MAM), a very similar trend is observed across the states, where positive trends of about $2.1 \%-7.4 \% \mathrm{yr}^{-1}$ are observed in the northwest and a part of IGP, but negative trends (from $-3 \%$ to $-10 \% \mathrm{yr}^{-1}$ ) are estimated elsewhere. The trends are significant in the northwest, IGP, and the eastern states (Tamilnadu, Andhra, Odisha, West Bengal, Jharkhand, Telangana, Chhattisgarh and Assam). Premonsoon (MAM or spring) seasons with higher temperatures, lower rainfall and the unavailability of own farm irrigation facilities make most farmlands remain fallow. As a result, a negative trend in $\mathrm{NH}_{3}$ concentration is estimated all over India, except in the northwest and some parts of IGP.

In summer (monsoon, JJAS or Kharif), most regions exhibit insignificant positive trends $\left(0.24 \%-10 \% \mathrm{yr}^{-1}\right)$, except in the northwest. The northwest region shows a negative trend and is due to the particular cultivation (e.g. groundnut production in sandy soils) and the presence of less cultivatable desert lands there. In contrast, there are positive trends in $\mathrm{NH}_{3}$ concentration in most parts of India, in this season in which IGP shows the largest positive trend. Monsoon season coincides with the Kharif season, and there is an increase in the use of $\mathrm{N}$ fertilizers (including urea) to get higher yields of paddy in farmlands; explains the increase in $\mathrm{NH}_{3}$ concentration during the period.

The trends in ON are similar to that of summer and are mostly negative and insignificant $\left(-0.3 \%--9 \% \mathrm{yr}^{-1}\right)$, except in Rajasthan and lower IGP where the trends are positive $\left(0.7 \%-6 \% \mathrm{yr}^{-1}\right)$. In general, the annual atmospheric $\mathrm{NH}_{3}$ shows significant positive trends in some parts of IGP and western India ( $\left.2 \%-7 \% \mathrm{yr}^{-1}\right)$, and significant negative trends (from $-2 \%$ to $-9 \% \mathrm{yr}^{-1}$ ) in Telangana and Andhra. The lower temperatures and high humidity favor gas to particle conversion in the post-monsoon (ON) and winter (DJF) seasons, and thus make a smaller $\left(\mathrm{ON}=-0.009 \times 10^{16} \mathrm{~mol} \mathrm{~cm}^{-2} \mathrm{yr}^{-1}\right.$ and $\mathrm{DJF}=-0.01 \times$ $\left.10^{16} \mathrm{~mol} \mathrm{~cm}^{-2} \mathrm{yr}^{-1}\right) \mathrm{NH}_{3}$ concentration in these seasons. Additionally, the central India shows a negative trend, and IGP and Northwest India show a mixture of both positive and negative trends in accordance with the agricultural activities and meteorology of the regions in the pre-monsoon and winter seasons. Since the ammonia values are very small, except in IGP and nearby regions, caution must be exercised when interpreting and comparing the higher trend values estimated for the other regions (e.g. $-10 \% \mathrm{yr}^{-1}$ in the southeast).

Recent studies indicate that there is a significant increase in atmospheric $\mathrm{NH}_{3}$ concentrations across the latitudes, although our studies show decreasing trends in most seasons. For example, an insignificant positive trend was estimated using the AIRS annual $\mathrm{NH}_{3}$ data during the period 2002-2014 for the south Asia region by Warner et al (2017), about $0.0098 \pm 0.019 \mathrm{ppbv} \mathrm{yr}^{-1}$. The positive trends estimated over China in that study are also confirmed by the analyses of Fu et al. (2020) in which they find a 2.4 fold increase in atmospheric $\mathrm{NH}_{3}$ from 1980 to 2016 from model results. These estimates are further corroborated by the findings of Zeng and Li (2020), as they observe $0.74 \%$ $\mathrm{yr}^{-1}$ of increase in atmospheric $\mathrm{NH}_{3}$ over the North China Plain. The study also shows that there are positive trends in atmospheric $\mathrm{NH}_{3}$ over the agricultural areas of the United States, China and Europe, about $1.8-2.61 \%$, depending on regions. In a similar study, Yu et al. (2018) find positive trends of $\mathrm{NH}_{3}$ over the United States during the period 2001-2016, as analysed from model results and AMoN (Ammonia Monitoring Network) data. The trends range from $0 \%-5 \% \mathrm{yr}^{-1}$ at the West to $5 \%-12 \% \mathrm{yr}^{-1}$ at the East, but a slight positive or negative trend at the hotspot regions as we found over IGP. Therefore, although there is a global increase in atmospheric $\mathrm{NH}_{3}$, a slight reduction is observed over India in most seasons.

\section{Conclusions}

The seasonal and inter-annual variability and trends in atmospheric $\mathrm{NH}_{3}$ during the period 2008-2016 are assessed using the 

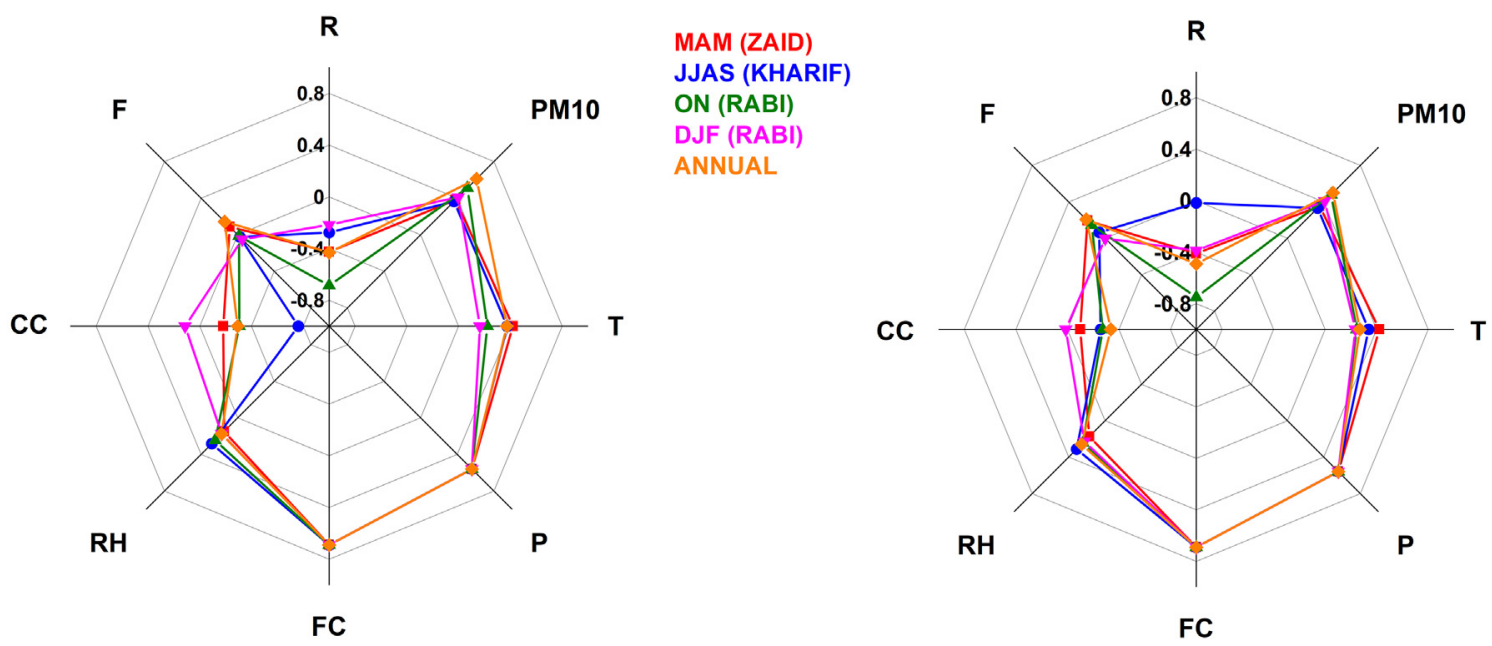

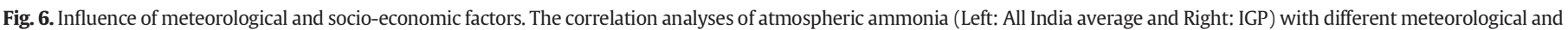

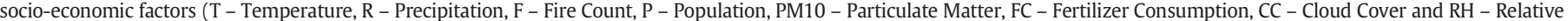
Humidity. The data are averaged for the respective seasons and over the complete observation period (2008-2016, and 2008-2015 for PM 10 , and rainfall).

IASI satellite observations. Agriculture, in its conventional form, contributes significantly to the atmospheric emission of gaseous $\mathrm{NH}_{3}$. The highest $\mathrm{NH}_{3}$ concentration is observed over IGP during monsoon (Kharif) season due to highly cultivated farmlands and a large number of fertilizer plants there. In contrast, the winter season shows a reduction in $\mathrm{NH}_{3}$ concentration over India because of wet deposition and gas to particle conversion. These facts strongly suggest that $\mathrm{NH}_{3}$ plays a key role in the deterioration of air quality over the whole of India by actively contributing to the formation of secondary aerosols. The high temperature favors $\mathrm{NH}_{3}$ volatilization, although precipitation is anti-correlated with high $\mathrm{NH}_{3}$ concentration. The total fertilizer consumption is found to be positively correlated with a high $\mathrm{NH}_{3}$ amount; implying the large inter-annual variability in $\mathrm{NH}_{3}$ due to the monthly, seasonal, and annual changes in agricultural practices. Therefore, regulations on the amount of fertilizer application in cropping seasons in arable lands, which might be plant demandbased (precision farming), in place of conventional blanket recommendation practices, are needed to cut the emissions from agricultural sector. The connection between atmospheric $\mathrm{NH}_{3}$ and $\mathrm{PM}$ formation is clear from the analyses; bolstering the theoretical understanding of the chemical conversion. Decreasing trends (from $-0.2 \%$ to $-10 \% \mathrm{yr}^{-1}$ ) in annual $\mathrm{NH}_{3}$ over India are in agreement with its pledge to reduce atmospheric emissions. However, as IGP still shows increasing trends $\left(3.5 \%-9.5 \% \mathrm{yr}^{-1}\right)$ in some seasons (e.g. Kharif), India still needs more efforts to reduce its $\mathrm{NH}_{3}$ emissions through improved fertilizer management. The increase in the levels of atmospheric aerosols, on the other hand, would have detrimental effects on the health of humans, ecosystems and climate; suggesting the importance of the analyses presented in this study.

\section{Declaration of competing interest}

The authors confirm that there are no known conflicts of interest associated with this article. The authors have no competing interests as defined by the Publishing Group, or other interests that might be perceived to influence the results and/or discussion reported in this paper.

\section{Acknowledgements}

We thank Indian Institute of Technology Kharagpur; Ministry of Human Resource Development; the Department of Science and
Technology (DST/SPLICE); Naval Research Board (OEP), Defense Research Development Organization; National Centre for Ocean Information Services Hyderabad and Ministry of Earth Science (MoES) for facilitating and funding the study. We also thank all the data managers and the scientists who made available those data for this study. We thank IMD (India Meteorological Department/MoES for precipitation and temperature data. HV thanks Indian Institute of Tropical Meteorology Pune/MoES funding for his research. The MODIS datasets were acquired from the Level- 1 and Atmosphere Archive \& Distribution System (LAADS) Distributed Active Archive Center (DAAC), located in the Goddard Space Flight Center in Greenbelt, Maryland (https://ladsweb.nascom.nasa.gov/). IASI is a joint mission of Eumetsat and the Centre National d'Etudes Spatiales (CNES, France). The authors acknowledge the Aeris data infrastructure for providing access to the IASI $\mathrm{NH}_{3}$ data used in this study. Cathy Clerbaux is grateful to CNES and Centre National de la Recherche Scientifique (CNRS) for financial support. Part of the research at the ULB has been supported by the IASI-Flow Prodex arrangement (ESA-BELSPO). Lieven Clarisse and Martin Van Damme are respectively a research associate and a postdoctoral researcher supported by the F.R.S.-FNRS.

\section{Data availability}

The data used this study are publically available. The PM10 data are on India government data website: https://data.gov.in/catalog/ historical-daily-ambient-air-quality-data. The MODIS fire data are on https://neo.sci.gsfc.nasa.gov/view.php?datasetId=MOD14A1_ M_FIRE. The ERA-interrim data are available on: https://www. ecmwf.int/en/forecasts/datasets/reanalysis-datasets/era-interim. The Indian population Census data can be found on: http:// censusindia.gov.in/2011census/population_enumeration.html). The IASI data can be accessed through http://iasi.aeris-data.fr/ $\mathrm{NH} 3 /$.

\section{Code availability}

The analyses codes are available on request.

\section{Appendix A. Supplementary data}

Supplementary data to this article can be found online at https://doi. org/10.1016/j.scitotenv.2020.139986. 


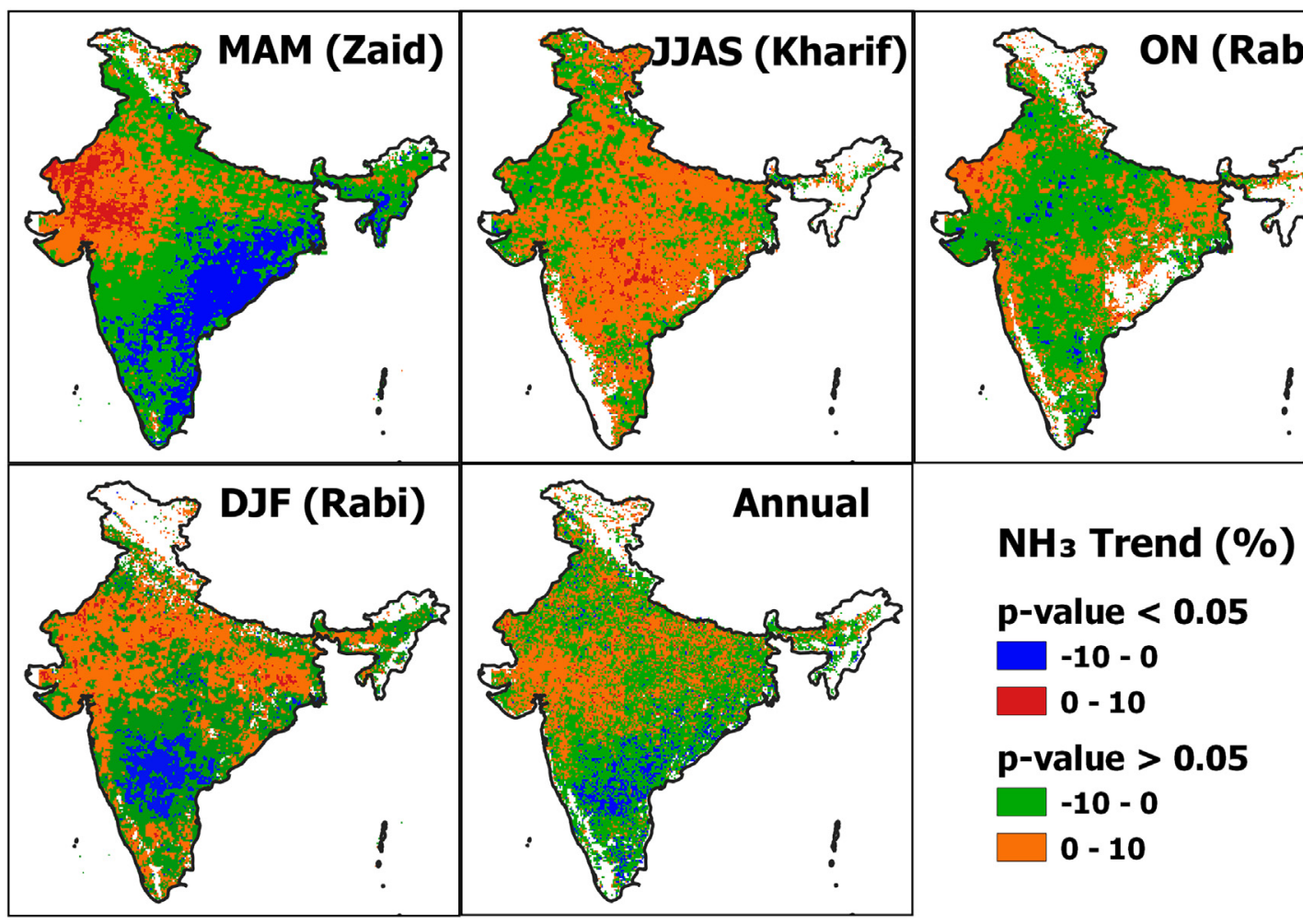

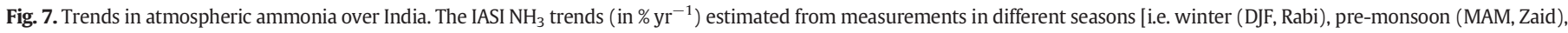
monsoon (JJAS, Kharif), post-monsoon (ON, Rabi)] and annual average over India for the period 2008-2016.

\section{References}

Adams, P.J., Seinfeld, J.H., Koch, D., Mickley, L., Jacob, D., 2001. General circulation mode assessment of direct radiative forcing by the sulfate-nitrate-ammonium-water inorganic aerosol system. J. Geophys. Res. 106, 1097-1111. https://doi.org/10.1029/ 2000JD900512.

Adams, C., et al., 2019. Satellite-derived emissions of carbon monoxide, ammonia, and nitrogen dioxide from the 2016 Horse River wildfire in the Fort McMurray area. Atmos. Chem. Phys. 19, 2577-2599. https://doi.org/10.5194/acp-19-2577-2019.

Banerjee, B., Pathak, H., Aggarwal, P.K., 2002. Effects of dicyandiamide, farmyard manure and irrigation on crop yields and ammonia volatilization from an alluvial soil under a rice (Oryza sativa L.)-wheat (Triticum aestivum L.) cropping system. Biol. Fertil. Soils 36, 207-214. https://doi.org/10.1007/s00374-002-0528-7.

Behera, S.N., Sharma, M., Aneja, V.P., Balasubramanian, R., 2013. Ammonia in the atmosphere: a review on emission sources, atmospheric chemistry and deposition on terrestrial bodies. Environ. Sci. Pollut. Res. https://doi.org/10.1007/s11356-013-2051-9.

Berden, G., Peeters, R., Meijer, G., 2000. Cavity ring-down spectroscopy: experimental schemes and applications. Int. Rev. Phys. Chem. https://doi.org/10.1080/ 014423500750040627.

Blaurock-Busch, E., Busch, Y.M., Friedle, A., Buerner, H., Parkash, C., Kaur, A., 2014. Comparing the metal concentration in the hair of cancer patients and healthy people living in the Malwa region of Punjab, India. Clin. Med. Insights Oncol. 8, 1-13. https:// doi.org/10.4137/CMO.S13410.

Bouwman, A.F., et al., 1997. A global high-resolution emission inventory for ammonia. Glob. Biogeochem. Cycles 11, 561-587. https://doi.org/10.1029/97GB02266.

Bouwman, A.F., Boumans, L.J.M., Batjes, N.H., 2002. Estimation of global NH 3 volatilization loss from synthetic fertilizers and animal manure applied to arable lands and grasslands. Global Biogeochem. Cycles 16, 8-1-8-14. doi:https://doi.org/10.1029/ 2000gb001389.

Bray, C.D., Battye, W., Aneja, V.P., Tong, D.Q., Lee, P., Tang, Y., 2018. Ammonia emissions from biomass burning in the continental United States. Atmos. Environ. 187, 50-61. https://doi.org/10.1016/j.atmosenv.2018.05.052.

Bray, Casey D., Battye, William H., Aneja, Viney P., 2019. The role of biomass burning agricultural emissions in the Indo-Gangetic Plains on the air quality in New Delhi, India. Atmos. Environ. 218. https://doi.org/10.1016/j. atmosenv.2019.116983.

Chang, Y., Deng, C., Dore, A.J., Zhuang, G., 2015. Human excreta as a stable and important source of atmospheric ammonia in the megacity of Shanghai. PLoS One 10, e0144661. https://doi.org/10.1371/journal.pone.0144661.

Chen, S., Cheng, M., Guo, Z., Xu, W., Du, X., Li, Y., 2020. Enhanced atmospheric ammonia (NH3) pollution in China from 2008 to 2016: evidence from a combination of observations and emissions. Environ. Pollut. 263. https://doi.org/10.1016/j. envpol.2020.114421.
Clarisse, L, Clerbaux, C., Dentener, F. Hurtmans, D., Coheur, P.F, 2009. Global ammonia distribution derived from infrared satellite observations. Nat. Geosci. https://doi. org/10.1038/ngeo551.

Clarisse, L., et al., 2010. Satellite monitoring of ammonia: a case study of the San Joaquin Valley. J. Geophys. Res. Atmos. 115. https://doi.org/10.1029/2009JD013291.

Clarisse, Lieven, Van Damme, M., Clerbaux, C., Coheur, P.-F., 2019a. Tracking down globa NH3 point sources with wind-adjusted superresolution. Atmos. Meas. Tech. 12, 5457-5473. https://doi.org/10.5194/amt-12-5457-2019.

Clarisse, L., et al., 2019b. Atmospheric ammonia $\left(\mathrm{NH}_{3}\right)$ emanations from Lake Natron's saline mudflats. Sci. Rep. 9. https://doi.org/10.1038/s41598-019-39935-3.

Clerbaux, C., et al., 2009. Monitoring of atmospheric composition using the thermal infrared IASI/MetOp sounder. Atmos. Chem. Phys. 9, 6041-6054. https://doi.org/10.5194/ acp-9-6041-2009.

Crippa, M., et al., 2018. Gridded emissions of air pollutants for the period 1970-2012 within EDGAR v4.3.2. Earth Syst. Sci. Data 10, 1987-2013. https://doi.org/10.5194/ essd-10-1987-2018.

Dammers, E., et al., 2015. Retrieval of ammonia from ground-based FTIR solar spectra. Atmos. Chem. Phys. 15, 12789-12803. https://doi.org/10.5194/acp-15-12789-2015.

Datta, A., Sharma, S.K., Harit, R.C., Kumar, V., Mandal, T.K., Pathak, H., 2012. Ammonia emission from subtropical cropland area in India. Asia-Pacific J. Atmos. Sci. 48 275-281. https://doi.org/10.1007/s13143-012-0027-1.

David, L.M., Ravishankara, A.R., Kodros, J.K., Pierce, J.R., Venkataraman, C., Sadavarte, P. 2019. Premature mortality due to PM2.5 over India: effect of atmospheric transport and anthropogenic emissions. Geo Health 3, 2-10. https://doi.org/10.1029/ 2018GH000169.

Dee, D.P., et al., 2011. The ERA-interim reanalysis: configuration and performance of the data assimilation system. Q. J. R. Meteorol. Soc. 137, 553-597. https://doi.org/ 10.1002/qj.828.

Ellis, R.A., Murphy, J.G., Markovic, M.Z., VandenBoer, T.C., Makar, P.A., Brook, J., Mihele, C., 2011. The influence of gas-particle partitioning and surface-atmosphere exchange on ammonia during BAQS-Met. Atmos. Chem. Phys. 11, 133-145. https://doi.org/ 10.5194/acp-11-133-2011.

Fan, X.H., Li, Y.C., Alva, A.K., 2011. Effects of temperature and soil type on ammonia volatilization from slow-release nitrogen fertilizers. Commun. Soil Sci. Plant Anal. 42 1111-1122. https://doi.org/10.1080/00103624.2011.566957.

Friedl, M.A., et al., 2002. Global land cover mapping from MODIS: algorithms and early results. Remote Sens. Environ. 83, 287-302. https://doi.org/10.1016/S0034-4257(02) 00078-0.

Fu, H., Luo, Z., Hu, S., 2020. A temporal-spatial analysis and future trends of ammonia emissions in China. Sci. Total Environ. 731. https://doi.org/10.1016/j. scitotenv.2020.138897.

Gong, L., et al., 2013. Role of atmospheric ammonia in particulate matter formation in Houston during summertime. Atmos. Environ. 77, 893-900. https://doi.org/ 10.1016/j.atmosenv.2013.04.079. 
Gupta, A., Kumar, R., Kumari, K.M., Srivastava, S.S., 2003. Measurement of $\mathrm{NO}_{2}, \mathrm{HNO}_{3}, \mathrm{NH}_{3}$ and $\mathrm{SO}_{2}$ and related particulate matter at a rural site in Rampur, India. Atmos. Environ. 37, 4837-4846. https://doi.org/10.1016/j.atmosenv.2003.07.008.

Harren, F.J.M., Mandon, J., Cristescu, S.M., 2012. Photoacoustic spectroscopy in trace gas monitoring. Encyclopaedia of Analytical Chemistry. John Wiley \& Sons, Ltd. https:// doi.org/10.1002/9780470027318.a0718.pub2.

Hegg, D.A., Radke, L.F., Hobbs, P.V., Riggan, P.J., 1988. Ammonia emissions from biomass burning. Geophys. Res. Lett. 15, 335-337. https://doi.org/10.1029/GL015i004p00335.

A special report on global exposure to air pollution and its disease burden: what is the state of global air? Who is it for? How can I explore the data? https://www. stateofglobalair.org/sites/default/files/soga_2019_report.pdf

Klimont, Z., 2001. Current and Future Emissions of Ammonia in China. 10th International Emission Inventory Conference - One Atmosphere, One Inventory, Many Challenges, US EPA, http://www.epa.gov/ttn/chief/conference/ei10/ammonia/klimont.pdf, last access: 22 December 2008 (2001).

Kulshrestha, U.C., Granat, L., Engardt, M., Rodhe, H., 2005. Review of precipitation monitoring studies in India - a search for regional patterns. Atmos. Environ. 39, 7403-7419. https://doi.org/10.1016/j.atmosenv.2005.08.035.

Kumar, L.M.P., Indira, M., 2017. Trends in fertilizer consumption and foodgrain production in India: a co-integration analysis. SDMIMD J. Manag. 8, 45-50. https://doi.org/ 10.18311/SDMIMD/2017/18025.

Lachatre, M., et al., 2019. The unintended consequence of SO 2 and NO 2 regulations ove China: increase of ammonia levels and impact on PM 2.5 concentrations. Atmos. Chem. Phys. 19, 6701-6716. https://doi.org/10.5194/acp-19-6701-2019.

Leen, J.B., Yu, X.Y., Gupta, M., Baer, D.S., Hubbe, J.M., Kluzek, C.D., Tomlinson, J.M., Hubbell, M.R., 2013. Fast in situ airborne measurement of ammonia using a mid-infrared offaxis ICOS spectrometer. Environ. Sci. Technol. 47, 10446-10453. https://doi.org/ 10.1021/es401134u.

Li, Y., et al., 2017. Temporal and spatial variability of ammonia in urban and agricultura regions of northern Colorado, United States. Atmos. Chem. Phys. 17, 6197-6213. https://doi.org/10.5194/acp-17-6197-2017.

Liu, L., Zhang, X., Xu, W., Liu, X., Li, Y., Lu, X., Zhang, Y., Zhang, W., 2017. Temporal characteristics of atmospheric ammonia and nitrogen dioxide over China based on emission data, satellite observations and atmospheric transport modeling since 1980. Atmos. Chem. Phys. 17, 9365-9378. https://doi.org/10.5194/acp-17-9365-2017.

Lou, Z., Wang, M., Zhao, Y., Huang, R., 2015. The contribution of biowaste disposal to odor emission from landfills. J. Air Waste Manage. Assoc. 65, 479-484. https://doi.org/ 10.1080/10962247.2014.1002870

Lutsch, E., et al., 2019. Unprecedented atmospheric ammonia concentrations detected in the high Arctic from the 2017 Canadian wildfires. J. Geophys. Res. Atmos. 124 8178-8202. https://doi.org/10.1029/2019JD030419.

Maji, S., Ghosh, S., Ahmed, S., 2018. Association of air quality with respiratory and cardiovascular morbidity rate in Delhi, India. Int. J. Environ. Health Res. 28, 471-490. https://doi.org/10.1080/09603123.2018.1487045

Murano, K., Mukai, H., Hatakeyama, S., Oishi, O., Utsunomiya, A., Shimohara, T., 1998. Wet deposition of ammonium and atmospheric distribution of ammonia and particulat ammonium in Japan. Nitrogen, the Confer-N-S. Elsevier, pp. 321-326. https://doi. org/10.1016/B978-0-08-043201-4.50048-4.

Nair, P.J., Chakraborty, A., Varikoden, H., Francis, P.A., Kuttippurath, J., 2018. The local and global climate forcings induced inhomogeneity of Indian rainfall. Sci. Rep. 8, 1-12. https://doi.org/10.1038/s41598-018-24021-x.

Nowak, J.B., et al., 2010. Airborne observations of ammonia and ammonium nitrate formation over Houston, Texas. J. Geophys. Res. Atmos. 115. https://doi.org/10.1029/ 2010JD014195.

Parashar, D.C., Kulshrestha, U.C., Sharma, C., 1998. Anthropogenic emissions of NO(x), $\mathrm{NH} 3$ and N2O in India. Nutrient Cycling in Agroecosystems. Springer, pp. 255-259. https://doi.org/10.1023/A:1009771907931.

Paulot, F., Jacob, D.J., Pinder, R.W., Bash, J.O., Travis, K., Henze, D.K., 2014. Ammonia emissions in the United States, European Union, and China derived by high-resolution inversion of ammonium wet deposition data: interpretation with a new agricultura emissions inventory (MASAGE_NH3). J. Geophys. Res. 119, 4343-4364. https://doi. org/10.1002/2013JD021130.

Potter, C., Klooster, S., Krauter, C., 2003. Regional modeling of ammonia emissions from native soil sources in California. Earth Interact. 7, 1-28. https://doi.org/10.1175/ 1087-3562(2003)007<0001:rmoaef $>2.0 . c 0 ; 2$.

Raj, S., Paul, S.K., Chakraborty, A., Kuttippurath, J., 2020. Anthropogenic forcing exacerbating the urban heat islands in India. J. Environ. Manag. 257. https://doi.org/10.1016/j. jenvman.2019.110006.

Rochette, P., et al., 2013. $\mathrm{NH}_{3}$ volatilization, soil $\mathrm{NH} 4+$ concentration and soil $\mathrm{pH}$ following subsurface banding of urea at increasing rates. Can. J. Soil Sci. 93, 261-268. https:// doi.org/10.4141/CJSS2012-095.

Roelle, P.A., Aneja, V.P., 2002. Characterization of ammonia emissions from soils in the upper coastal plain, North Carolina. Atmos. Environ. 36, 1087-1097. https://doi.org/ 10.1016/S1352-2310(01)00355-7.

Saikia, N., Bora, J.K., Jasilionis, D., Shkolnikov, V.M., 2016. Disability divides in India: evidence from the 2011 census. PLoS One 11, e0159809. https://doi.org/10.1371/journal.pone.0159809.

Sharma, M., Kishore, S., Tripathi, S.N., Behera, S.N., 2007. Role of atmospheric ammonia in the formation of inorganic secondary particulate matter: a study at Kanpur, India. J. Atmos. Chem. 58, 1-17. https://doi.org/10.1007/s10874-007-9074-X.

Sharma, B.D. Kumar, R, Manchanda, J.S, Dhaliwal, S. Thind, H.S., Singh, Y., 2016. Mapping of chemical characteristics and fertility status of intensively cultivated soils of Punjab, India. Commun. Soil Sci. Plant Anal. 47. https://doi.org/10.1080/00103624.2016.1208756.

Sharma, S.K., Kotnala, G., Mandal, T.K., 2020. Spatial variability and sources of atmospheric ammonia in India: a review. Aerosol Sci. Eng. https://doi.org/10.1007/s41810-019-00052-3.
Shephard, M.W., Cady-Pereira, K.E., 2015. Cross-track infrared sounder (CrIS) satellite observations of tropospheric ammonia. Atmos. Meas. Tech. 8, 1323-1336. https://doi. org/10.5194/amt-8-1323-2015

Sheppard, L.J., et al., 2011. Dry deposition of ammonia gas drives species change faster than wet deposition of ammonium ions: evidence from a long-term field manipulation. Glob. Chang. Biol. 17, 3589-3607. https://doi.org/10.1111/j.1365-2486.2011.02478.x.

Singh, S., Kulshrestha, U.C., 2012. Abundance and distribution of gaseous ammonia and particulate ammonium at Delhi, India. Biogeosciences 9, 5023-5029. https://doi. org/10.5194/bg-9-5023-2012.

Sintermann, J., Dietrich, K., Häni, C., Bell, M., Jocher, M., Neftel, A., 2016. A mini-DOAS instrument optimised for ammonia field measurements. Atmos. Meas. Tech. 9, 2721-2734. https://doi.org/10.5194/amt-9-2721-2016.

Someya, Y., Imasu, R., Shiomi, K., Saitoh, N., 2020. Atmospheric ammonia retrieval from the TANSO-FTS/GOSAT thermal infrared sounder. Atmos. Meas. Tech. 13, 309-321. https://doi.org/10.5194/amt-13-309-2020.

Sun, K., Tao, L., Miller, D.J., Khan, M.A., Zondlo, M.A., 2014. On-road ammonia emissions characterized by mobile, open-path measurements. Environ. Sci. Technol. 48, 3943-3950. https://doi.org/10.1021/es4047704.

Sutton, M.A. Pitcairn, C.E.R., Fowler, D. 1993. The exchange of ammonia between the atmosphere and plant communities. Adv. Ecol. Res. 24, 301-393. https://doi.org/ 10.1016/S0065-2504(08)60045-8.

Tang, Y.S., et al., 2018. Drivers for spatial, temporal and long-term trends in atmospheric ammonia and ammonium in the UK. Atmos. Chem. Phys. 18, 705-733. https://doi. org/10.5194/acp-18-705-2018.

Tanvir, A., Khokhar, M.F., Javed, Z., Sandhu, O., Mustansar, T., Shoaib, A., Tariq, S., 2019. Spatiotemporal Evolution of Atmospheric Ammonia Columns Over the Indo-Gangetic Plain by Exploiting Satellite Observations. https://doi.org/10.1155/2019/7525479.

Tian, D., Niu, S., 2015. A global analysis of soil acidification caused by nitrogen addition. Environ. Res. Lett. 10, 024019. https://doi.org/10.1088/1748-9326/10/2/024019.

Upadhyay, G., Ray, S.S., Panigrahy, S., 2008. Derivation of crop phenological parameters using multi-date SPOT-VGT-NDVI data: a case study for Punjab. J. Indian Soc. Remote Sens. 36, 37-50. https://doi.org/10.1007/s12524-008-0004-4.

Van Damme, M., et al., 2014a. Global distributions, time series and error characterization of atmospheric ammonia (NH3) from IASI satellite observations. Atmos. Chem. Phys. 14, 2905-2922. https://doi.org/10.5194/acp-14-2905-2014.

Van Damme, M., et al., 2014b. Evaluating 4 years of atmospheric ammonia (NH3) over Europe using IASI satellite observations and LOTOS-EUROS model results. J. Geophys. Res. 119, 9549-9566. https://doi.org/10.1002/2014JD021911.

Van Damme, M., et al., 2015. Towards validation of ammonia (NH3) measurements from the IASI satellite. Atmos. Meas. Tech. 8, 1575-1591. https://doi.org/10.5194/amt-81575-2015.

Van Damme, M., Whitburn, S., Clarisse, L., Clerbaux, C., Hurtmans, D., Coheur, P.F., 2017. Version 2 of the IASI NH3 neural network retrieval algorithm: near-real-time and reanalysed datasets. Atmos. Meas. Tech. 10, 4905-4914. https://doi.org/10.5194/ amt-10-4905-2017.

Van Damme, M., et al., 2018. Industrial and agricultural ammonia point sources exposed. Nature 564, 99-103. https://doi.org/10.1038/s41586-018-0747-1.

Venkataraman, C., et al., 2006. Emissions from open biomass burning in India: integrating the inventory approach with high-resolution moderate resolution imaging spectroradiometer (MODIS) active-fire and land cover data. Glob. Biogeochem. Cycles 20. https://doi.org/10.1029/2005GB002547.

Viatte C, V, et al., 2020. Atmospheric ammonia variability and link with PM formation: a case study over the Paris area. Atmospheric Chem. Phys. 20, 577-596.

Warner, J.X., Wei, Z., Strow, L.L., Dickerson, R.R., Nowak, J.B., 2016. The global tropospheric ammonia distribution as seen in the 13-year AIRS measurement record. Atmos. Chem. Phys. 16, 5467-5479. https://doi.org/10.5194/acp-16-5467-2016.

Warner, J.X., Dickerson, R.R., Wei, Z., Strow, L.L., Wang, Y., Liang, O., 2017. Increased atmospheric ammonia over the world's major agricultural areas detected from space NASA Public Access. Geophys Res Lett. (March 28), 2875-2884 https://doi.org/10.1002/ 2016GL072305.

Whitburn, S., et al., 2016a. A flexible and robust neural network IASI-NH3 retrieval algorithm. J. Geophys. Res. 121, 6581-6599. https://doi.org/10.1002/2016JD024828.

Whitburn, S., Van Damme, M., Clarisse, L., Turquety, S., Clerbaux, C., Coheur, P.F., 2016b. Doubling of annual ammonia emissions from the peat fires in Indonesia during the 2015 El Niño. Geophys. Res. Lett. 43, 11007-11014. https://doi.org/10.1002/ 2016GL070620

Whitburn, S., Van Damme, M., Clarisse, L., Hurtmans, D., Clerbaux, C., Coheur, P.-F., 2017. IASI-derived $\mathrm{NH} 3$ enhancement ratios relative to $\mathrm{CO}$ for the tropical biomass burning regions. Atmos. Chem. Phys. 17, 12239-12252. https://doi.org/10.5194/acp-1712239-2017.

Wu, J., et al., 2018. Estimating the open biomass burning emissions in central and eastern China from 2003 to 2015 based on satellite observation. Atmos. Chem. Phys. 18, 11623-11646. https://doi.org/10.5194/acp-18-11623-2018.

Xu, R.T., Pan, S.F., Chen, J., Chen, G.S., Yang, J., Dangal, S.R.S., Shepard, J.P., Tian, H.Q., 2018. Half-century ammonia emissions from agricultural systems in Southern Asia: magnitude, spatiotemporal patterns, and implications for human health. GeoHealth 2, 40-53. https://doi.org/10.1002/2017GH000098.

Yu, F. Nair, A.A., Luo, G., 2018. Long-term trend of gaseous ammonia over the United States: modeling and comparison with observations. J. Geophys. Res. Atmos. 123, 8315-8325. https://doi.org/10.1029/2018JD028412.

Zeng, W., Li, J., 2020. Spatio-temporal distribution of ammonia $\left(\mathrm{NH}_{3}\right)$ emissions in agricultural fields across North China. Environ. Sci. Pollut. Res. 27, 8129-8141. https://doi. org/10.1007/s11356-019-07326-w.

Zhang, Y., Dore, A.J., Ma, L., Liu, X.J., Ma, W.Q., Cape, J.N., Zhang, F.S., 2010. Agricultural ammonia emissions inventory and spatial distribution in the North China plain. Environ. Pollut. 158, 490-501. https://doi.org/10.1016/J.ENVPOL.2009.08.033. 